\title{
Influence of Milk Type, Coagulant, Salting Procedure and Ripening Time on the Final Characteristics of Picante Cheese
}

\author{
A. Cristina Freitas \& F. Xavier Malcata* \\ Escola Superior de Biotecnologia, Universidade Católica Portuguesa, Rua Dr. António \\ Bernardino de Almeida, 4200 Porto, Portugal
}

\begin{abstract}
Picante da Beira Baixa cheese is a hard, spicy, salty traditional cheese with a minimum ripening time of $120 \mathrm{~d}$ that is manufactured in Portugal at a farm level only. The purpose of this work was to study the influence of several manufacturing conditions (viz. mixture of ovine and caprine milks, source of coagulant, level of $\mathrm{NaCl}$ addition, and duration of ripening period) on the final characteristics of this cheese following a (replicated) factorial design. Milk type proved to be a statistically significant technological parameter in terms of numbers of viable microorganisms of various genera and the extent of proteolysis, probably as a consequence of higher initial contamination of caprine milk. The type of coagulant had a major effect on proteolysis: values of water-soluble nitrogen for cheeses coagulated with animal rennet were in general lower than those for cheeses coagulated with plant rennet, but much smaller differences were detected between values of non-protein nitrogen; and breakdown of $\alpha_{s}$-and $\beta$-caseins was more extensive in Picante cheeses manufactured with plant rennet. The level of $\mathrm{NaCl}$ was a statistically significant parameter for all microbiological, physicochemical and chemical characteristics measured, an observation that is probably due to its capacity to reduce water activity. Ripening time did not have a significant effect on the numbers of viable staphylococci. Copyright $(\mathcal{C} 1996$ Elsevier Science Limited
\end{abstract}

\section{INTRODUCTION}

Sheep and goats were among the first milk-producing animals to be domesticated and cheeses in various forms have been manufactured from their milks ever since.

*Author to whom correspondence should be addressed. 
Production of ovine and caprine milk cheeses in Europe has been concentrated in Mediterranean countries (Biss, 1991), and nowadays researchers in such countries have been consistently developing an interest in the characterization and improvement of such products. Picante da Beira Baixa (or simply Picante) is a traditional cheese manufactured in Portugal from mixtures of ovine and caprine milks, and it currently possesses an Appellátion d'Origine Controllée status. This hard, salty, spicy cheese originates from the central regions of Portugal where it is manufactured manually in small quantities at a farm level only (Cruz, 1945).

Thistle flowers (Cynara cardunculus L.) have been used since ancient times for farm production of various types of Portuguese ovine milk cheeses (Barbosa $e t$ al., 1981). In attempts to assess the feasibility of using alternative coagulants as substitutes for traditional animal rennet, studies on the aforementioned plant rennet are of interest. On the other hand, the ratio of ovine and caprine milks used for the manufacture of Picante cheese varies considerably from farm to farm, probably as a result of the actual composition of (mixed) flocks. The duration of ripening is known to considerably affect the extent of breakdown reactions in cheese, and has accordingly often been implicated in the final flavour intensity of Picante cheese. The $\mathrm{NaCl}$ content of Picante cheese is usually quite high and may reach a final value of 10-12\% (Freitas et al., 1996) which is inhibitory or even lethal to a variety of microorganisms often found in cheese. In view of the aforementioned description, the type of rennet used to coagulate the cheese milk, the proportions of ovine and caprine milks used for cheesemaking, the amount of $\mathrm{NaCl}$ applied to the surface of the cheese and the duration of ripening are four important parameters in cheese technology, and so attempts to assess their effects on the final characteristics of Picante cheese have provided the impetus for this research work.

\section{MATERIALS AND METHODS}

\section{Cheese manufacture}

A randomised $2^{4}$ complete factorial design without blocking and replicated twice was followed in the experimental layout; hence, two milk blends, two coagulants, two levels of $\mathrm{NaCl}$, and two ripening times were assessed in terms of physicochemical, chemical and microbiological profiles of the cheese. The manufacture of the aforementioned 32 cheeses was based on the traditional protocol for Picante, i.e. mixturcs of raw ovine and caprine milks (without fat standardization) are coagulated with animal rennet without addition of a starter culture at ca. $29^{\circ} \mathrm{C}$ for ca. $50 \mathrm{~min}$. The curd is cut (with $1.5 \mathrm{~cm}$-spaced wires) and allowed to rest for ca. $10 \mathrm{~min}$ to help in syneresis of whey; the curd is then poured into metal perforated cylindrical moulds where it is lightly pressed by hand. After manufacture, the fresh cheeses are rubbed with an amount of dry salt sufficient to create an almost continuous layer of salt on the whole cheese surface, and maintained in the maturation room for 2-6 d (during this period, the cheeses are turned upside down several times). After this initial period, the cheeses are rubbed once again with salt, grouped in small horizontal sets of 2 or 3 cheeses, and left in that way for 2-3 weeks. After the proper consistency has been attained (a status that is empirically assessed by the cheese maker), these sets are brought together in vertical sets 
of several cheeses supported by intercalated layers of clean sand and wheat straw, and maintained in that way for a minimum of 4 months (during this period, the cheeses are periodically washed with tap or salted water). The ripening temperature and relative humidity are determined by the outer weather only, and the ripening process allows the cheeses to develop their major properties of hardness, saltiness and spiciness; the final cheeses are ca. $1000 \mathrm{~g}$ in weight, ca. $12.0 \mathrm{~cm}$ in diameter, and ca. $5 \mathrm{~cm}$ in height. In this work, modifications of the traditional method were performed to obtain quantitative data (on statistically sound grounds) pertaining to the technological aspects under study: cheeses were produced using two milk blends $(20-80 \%$ and $40-$ $60 \%, \mathrm{v} / \mathrm{v}$, of caprine and ovine milks); plant rennet or regular calf rennet was used to coagulate the milk; one half of the cheeses were salted only once, immediately after manufacture while the other half were salted twice; and two ripening times, 30 and $120 \mathrm{~d}$, were evaluated. Shorthand codes will be used hereafter to denote each experimental cheese; the meanings of these codes in terms of experimental conditions are summarized in Table 1. For Enterobacteriaceae counts, a randomised $2^{3}$ complete factorial design without blocking and replicated twice was followed; the effect of ripening time was not taken into account because preliminary trials had indicated that this group of microorganisms could not be detected in cheese at $120 \mathrm{~d}$. Assays for lipolysis could not be replicated due to laboratory constraints.

\section{Microbiological analyses}

Counts of total viable mesophilic microorganisms (TVMM), staphylococci, Enterobacteriaceae, yeasts and lactic acid bacteria (LAB) were determined as described by Freitas et al. (1995), using Plate Count Agar (Lab M, Bury, USA), Baird Parker Medium (Lab M), Violet Red Bile Glucose Agar (Lab M), Potato Dextrose Agar (Lab M) and de Man Rogosa Sharpe Agar (Lab M), respectively. For total counts of enterococci, sequencial decimal dilutions of cheese homogenates were plated on KF Streptococccus agar base (Merck, Frankfurt, Germany). All microbiological counts were made according to the

TABLE 1

Codes Used to Denote the Various Experimental Cheeses

\begin{tabular}{ll}
\hline Code & Meaning \\
\hline $\mathbf{2 0}$ & Mixture of $\mathbf{2 0} \%$ caprine and $80 \%$ ovine milk \\
$\mathbf{4 0}$ & Mixture of $\mathbf{4 0} \%$ caprine and $60 \%$ ovine milk \\
$\mathbf{P}$ & Plant rennet as coagulant \\
An & Animal rennet as coagulant \\
A & Single addition of salt \\
B & Double addition of salt \\
30d & 30 days of ripening \\
120d & 120 days of ripening
\end{tabular}

Example: 20 An A 30d denotes a cheese manufactured from $20 \%$ caprine milk, coagulated with animal rennet, salted once, and ripened for $30 \mathrm{~d}$ 
surface viable count technique of Miles \& Misra (1938), except for Enterobacteriaceae which were determined by the pour-plate technique of Busta et al. (1984).

\section{Physicochemical analyses}

Physicochemical analyses were according to Richardson (1985) and Kosikowski (1982). The $\mathrm{pH}$ was measured at two locations in the cheese (near the centre and at the surface) with an electrode for solids (Ingold, Urdorf, Switzerland) connected to a Microph 2001 potentiometer (Crison, Barcelona, Spain). The moisture content was determined by drying at $100^{\circ} \mathrm{C}$ in an oven from Memmert (Schwabach, Germany). The $\mathrm{NaCl}$ content was determined by the modified Volhard method using $\mathrm{AgNO}_{3}$ and $\mathrm{KCNS}$ (Merck). Water activity $\left(\mathrm{a}_{\mathrm{w}}\right)$ was measured with a CX-1 system (Decagon Devices, Pullman, USA). Fat content was determined by the Van Gulik method (Anon., 1975) using $40 \% \mathrm{H}_{2} \mathrm{SO}_{4}$ and isoamyl alcohol (Pronalab, Lisbon, Portugal).

\section{Chemical analysis}

Total nitrogen (TN), water soluble nitrogen (WSN) and non-protein nitrogen (NPN) were determined by the micro-Kjeldahl method using a Kjeltec system 1002 Distilling unit (Tecator, Höganäs, Sweden). A water-soluble extract (WSE) was prepared according to Kuchroo \& Fox (1982), followed by acidification to $\mathrm{pH} 4.3$ with $1.41 \mathrm{M} \mathrm{HCl}$ (Pronalab). The NPN fraction, i.e. the nitrogen fraction soluble in $12 \%$ trichloroacetic acid (TCA, Merck), was prepared by adding $7.5 \mathrm{~mL}$ of $48 \%$ (w/v) of TCA to $22.5 \mathrm{~mL}$ of WSE; the mixture was allowed to stand $30 \mathrm{~min}$ at room temperature and filtered through Whatman No. 42 filter paper (Maidstone, UK). PTA-N, i.e. the nitrogen fraction soluble in $5 \%$ phosphotungstic acid (PTA, Merck), was prepared by adding $14.0 \mathrm{~mL}$ of $\mathrm{H}_{2} \mathrm{SO}_{4}(3.95 \mathrm{M}$ ) (Pronalab) and $6 \mathrm{~mL}$ of $33.3 \%(\mathrm{w} / \mathrm{v})$ PTA to $20 \mathrm{~mL}$ of WSE; the mixture was allowed to stand overnight at $4^{\circ} \mathrm{C}$ and subsequentely filtered through Whatman No. 42 filter paper. The spectrophotometric method of Adler-Nissen (1979), with modifications, using 2,4,6trinitrobenzenesulphonic acid (Fluka Biochemika, Buchs, Switzerland) was used to quantify NPN and PTA-N. To distinguish the NPN results obtained by the Kjeldahl method from those obtained by the spectrophotometric method, the former will be designated as NPN and the latter as TCA-N. The evolution of amino acid nitrogen $\left(\mathrm{NH}_{2}-\mathrm{N}\right)$ was measured according to Folkertsma \& Fox (1992) using cadmium-ninhydrin (Sigma, St Louis MO, USA). Urea-polyacrylamide gel electrophoresis (PAGE) $(10.5 \% \mathrm{~T}, 4.8 \% \mathrm{C})$ was performed on cheese samples according to the method of Andrews (1983) with modifications using a Protean II XI vertical slab-gel unit (Bio-Rad Laboratories, Watford, UK). The cheese samples were prepared according to Farkye et al. (1991). The gels were stained with Coomassie Blue G-250 (BioRad, Richmond CA, USA) according to the method of Blakesley \& Boezi (1977). Ovine and caprine casein standards were purchased from Sigma.

Fat was extracted with diethyl ether (Merck, Darmstadt, Germany), according to Nuñez et al. (1986). Free fatty acids were titrated with $0.1 \mathrm{~N}$ ethanolic $\mathrm{KOH}$ to obtain a lipolysis index expressed as $\mathrm{mgequiv.KOH} \mathrm{g}_{\text {fat }}$. The profile of free fatty acids was determined by HPLC (Beckman, San Ramon CA, USA). To different 
volumes of diethyl ether extract, given volumes of a solution of internal standards ( $0.5 \mathrm{~g} \mathrm{~L}^{-1}$ of each $\mathrm{C} 9: 0$ and $\mathrm{C17}: 0$ from Sigma) were added prior to derivatization which was performed according to Garcia et al. (1990) using $p$-bromophenacylbromide (Sigma), 18-crown-6-ether and $\mathrm{K}_{2} \mathrm{CO}_{3}$ (Merck, Munchen, Germany), and formic acid (Romil, Leicester, UK). Separation was achieved using a C-18 reversed-phase column coupled with a pre-column cartridge (Beckman). Separation was effected at $33^{\circ} \mathrm{C}$ using a gradient of water with $5 \%$ of acetonitrile (Romil) (Solvent A) and methanol with $5 \%$ of acetonitrile (Romil) (Solvent B) at a flow-rate of $1 \mathrm{~mL} \mathrm{~min}^{-1}$ : the gradient steps were from $0 \%$ solvent $\mathrm{B}$ to $88.5 \%$ solvent B during the first $20 \mathrm{~min}$, to $100 \%$ solvent B during the following $11 \mathrm{~min}$, and to $52.5 \%$ solvent $B$ until the end of the run $(60 \mathrm{~min})$. The absorbance of the eluate was read at $254 \mathrm{~nm}$.

\section{Statistical analyses}

The following empiric model was tentatively fitted to the experimental data obtained in the 16 independent experiments:

$$
\begin{aligned}
\hat{y}=\bar{y} & +\alpha_{1} x_{1}+\alpha_{2} x_{2}+\alpha_{3} x_{3}+\alpha_{4} x_{4}+\alpha_{12} x_{1} x_{2}+\alpha_{13} x_{1} x_{3}+\alpha_{14} x_{1} x_{4}+\alpha_{23} x_{2} x_{3} \\
& +\alpha_{24} x_{2} x_{4}+\alpha_{34} x_{3} x_{4}+\alpha_{123} x_{1} x_{2} x_{3}+\alpha_{124} x_{1} x_{2} x_{4}+\alpha_{134} x_{1} x_{3} x_{4}+\alpha_{234} x_{2} x_{3} x_{4} \\
& +\alpha_{1234} x_{1} x_{2} x_{3} x_{4}
\end{aligned}
$$

where $\hat{y}$ is the fitted response, $\bar{y}$ is the average of all data, the $\alpha$ 's are adjustable parameters, and the $x$ 's are the technological variables manipulated expressed in normalized form (i.c. $x_{1}$ : effect of milk type, calculated as $(30-C) / 10$ where $C$ is the volumetric percentage of the blend in caprine milk; $x_{2}$ : effect of coagulant, equal to -1 for animal rennet and +1 for plant rennet; $x_{3}$ : effect of salting, equal to -1 for single addition of salt and +1 for double addition of salt; and $x_{4}$ : effect of ripening time, calculated as $(t-75) / 45$, where $t$ is the time expressed in day). Estimates of the effects of all processing parameters were obtained using the table of contrasts method as described by Box et al. (1978). In the case of Enterobacteriaceae, the following empiric model was tentatively fitted to the experimental data obtained in the eight independent experiments:

$$
\hat{y}=\bar{y}+\alpha_{1} x_{1}+\alpha_{2} x_{2}+\alpha_{3} x_{3}+\alpha_{12} x_{1} x_{2}+\alpha_{13} x_{1} x_{3}+\alpha_{23} x_{2} x_{3}+\alpha_{123} x_{1} x_{2} x_{3}
$$

Statistical analyses based on minimization of the squares of the residuals are valid if the experimental errors are independent and normally distributed, and if they possess a constant variance; for most variables, the original experimental data, $y$, had to be transformed according to a Box-Cox transformation, viz. $\frac{y^{\lambda}-1}{\lambda y^{\lambda-1}}$ (where $y$ is the geometric mean of the original data and $\lambda$ is a parameter) so as to achieve normality and stabilize variance (Box et al., 1978). Plots of the residuals of the transformed data (not shown) indicate that the behaviour of the errors of the transformed data were in good agreement with the assumptions underlying the validity of the variance analysis, and so the model-fitting routines and computation of the confidence intervals using the pooled replicate variance as estimator were statistically valid. In the case of lipolysis data, since no replicates were available, decision on which factors were relevant was taken using the normal probability plot technique (Box et al., 1978). 


\section{RESULTS AND DISCUSSION}

\section{Microbiology}

The experimental data for counts of total viable mesophilic microorganisms (TVMM), staphylococci, enterococci, LAB, yeasts and Enterobacteriaceae for the cheeses manufactured according to the various combinations of experimental factors are summarized in Table 2.

The counts of TVMM were statistically affected at the $5 \%$ level of significance by milk type, $\mathrm{NaCl}$ content and ripening time $\left(\alpha_{1}=-1.38 \times 10^{8}, \alpha_{3}=-3.91 \times 10^{8}\right.$ and $\alpha_{4}=-4.17 \times 10^{8}$, respectively, with $\lambda=-0.04$ ).

The counts of viable staphylococci were statistically affected at the $5 \%$ level of significance by milk type, coagulant and $\mathrm{NaCl}$ content $\left(\alpha_{1}=-1.87 \times 10^{6}\right.$, $=-4.515 \times 10^{5}$ and $\alpha_{3}=-1.67 \times 10^{6}$, respectively, with $\left.\lambda=-0.11\right)$. The use of animal rennet apparently favours growth of staphylococci.

The counts of viable Enterobacteriaceae were statistically affected at the 5\% level of significance by milk type and $\mathrm{NaCl}$ content $\left(\alpha_{1}=-1.27 \times 10^{5}\right.$ and $\alpha_{3}=-2.24 \times 10^{5}$, respectively, with $\lambda=0.13$ ). Enterobacteriaceae counts at $30 \mathrm{~d}$ of ripening were clearly different between the various experimental cheeses; higher values were observed in cheeses with a lower content of $\mathrm{NaCl}$ and lower $\mathrm{pH}$ values. Nuñez et al. (1985) and Gaya et al. (1983) claimed that lower $\mathrm{pH}$ values were a major factor in reducing the survival of coliforms in Manchego cheese. According to Marshall et al. (1971) and Measure (1975), water activity values below 0.95 are inhibitory to Enterobacteriaceae; by $120 \mathrm{~d}$ of ripening, this family of microorganisms was not detected in any cheese.

The counts of viable enterococci were statistically affected at the $5 \%$ level of significance by all manipulated variables $\left(\alpha_{1}=-2.32 \times 10^{6}, \alpha_{2}=9.4 \times 10^{5}\right.$, ${ }_{3}=-9.5 \times 10^{5}$ and $\alpha_{4}=-1.29 \times 10^{6}$, respectively, with $\left.\lambda=-0.08\right)$. Enterococci counts were affected by $\mathrm{NaCl}$ in a way similar to the other groups of microorganisms (Table 2); however, the difference between the values of cheeses $\mathbf{A}$ and B, especially after longer ripening times, were not high, indicating some resistance of these microorganisms to $\mathrm{NaCl}$. The statistical analysis of our experimental results suggested that plant rennet favours growth of enterococci. This observation might be rationalized by the work of Nuñez et al. (1991) on the effect of plant and animal rennets on La Serena cheese, who claimed that the plant rennet contributed to milk contamination, thus giving higher counts of total microorganisms, Enterobacteriaceae and coliforms.

The counts of LAB were statistically affected at the $5 \%$ level of significance by milk type, $\mathrm{NaCl}$ content and ripening time $\left(\alpha_{1}=-1.77 \times 10^{7}, \alpha_{3}=-8.29 \times 10^{7}\right.$ and $\alpha_{4}=-7.31 \times 10^{7}$, respectively, with $\left.\lambda=0.14\right)$. The results in Table 2 indicate that changes in the numbers of lactic acid bacteria (LAB) and yeasts with ripening time were strongly affected by the $\mathrm{NaCl}$ content. According to Schroeder et al. (1988), Cheddar cheese with reduced levels of $\mathrm{NaCl}$ supported high numbers of LAB.

The counts of viable yeasts were statistically affected at the $5 \%$ level of significance by all manipulated variables $\left(\alpha_{1}=-5.2 \times 10^{5}, \quad \alpha_{2}=1.9 \times 10^{5}\right.$, $3=-1.18 \times 10^{6}$ and $\alpha_{4}=-2.84 \times 10^{6}$, respectively, with $\lambda=-0.05$ ). In particular, the plant rennet led to higher mean counts, especially in the cheeses manufactured from $20 \%$ caprine milk.

In general, $\mathrm{NaCl}$ content and, to a lesser extent, the fraction of ovine milk in 


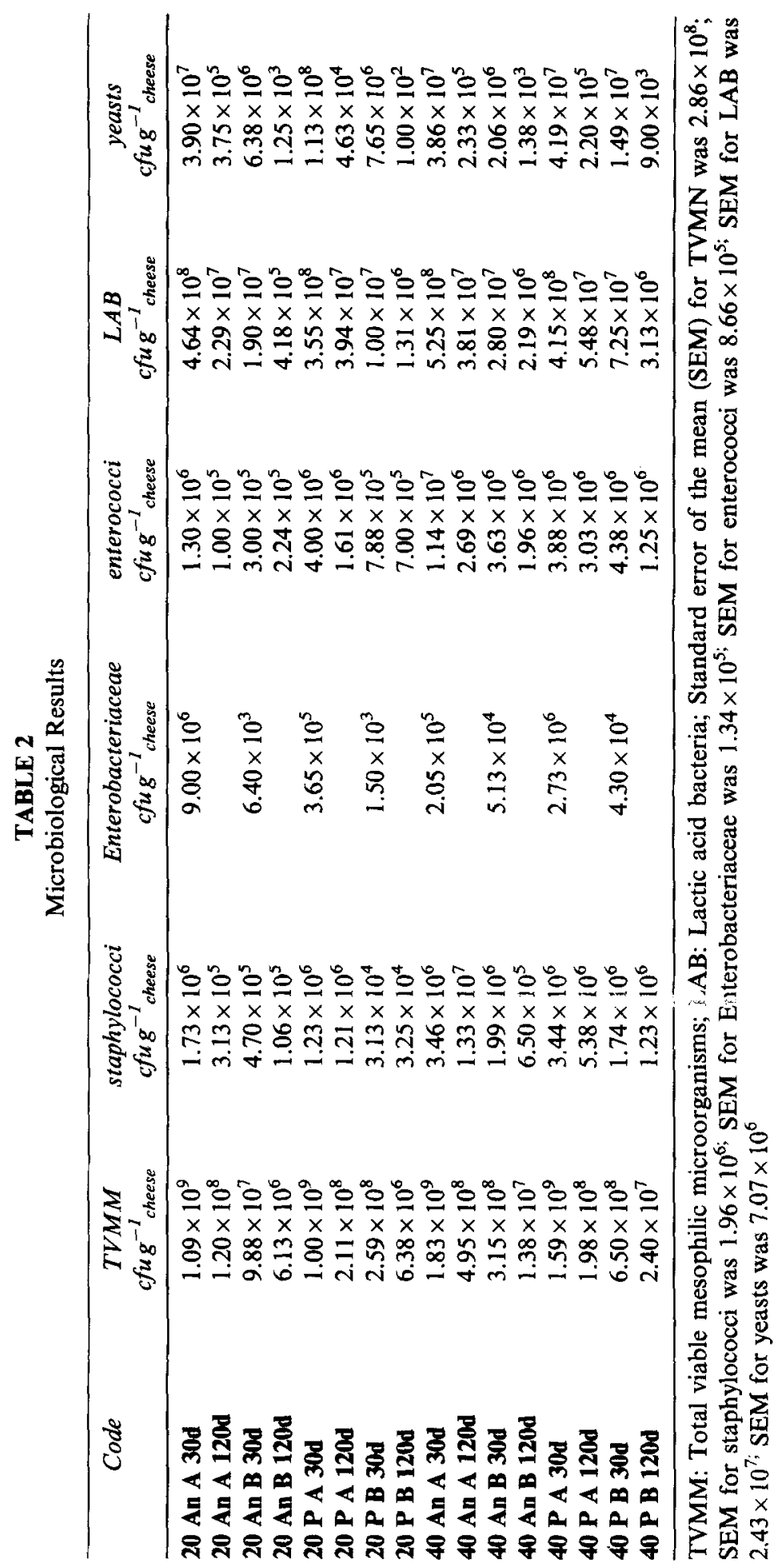


the milk blend had negative effects for all microbiological groups (i.e. higher values of either of these factors led to lower microbiological counts). The effect of milk type may have been due to the initial flora of the milks from the two animal sources; Table 2 suggests higher initial microbial contamination of the cheeses manufactured from $40 \%$ caprine milk. The effect of salt content on the microflora, as shown in Table 2, was not surprising due to the role of $\mathrm{NaCl}$ in increasing osmotic pressure and lowering water activity (Table 3 ), both of which have been commonly implicated in the control of microbial growth.

The various microbiological groups were affected differently by two-factor interactions. Those two-factor interactions most often found to be significant were milk type/coagulant and salting procedure/ripening time; the former was significant at the $5 \%$ level for the counts of viable Enterobacteriaceae $\left(\alpha_{12}=-1.30 \times 10^{5}\right.$ with $\left.\lambda=0.13\right)$, enterococci $\left(\alpha_{12}=1.33 \times 10^{6}\right.$ with $\left.\lambda=-0.08\right)$ and yeasts $\left(\alpha_{12}=-1.80 \times 10^{5}\right.$ with $\left.\lambda=-0.05\right)$, whereas the latter was significant at the same level for total mesophilic counts $\left(\alpha_{34}=-1.40 \times 10^{8}\right.$ with $\left.\lambda=-0.04\right)$, LAB $\left(\alpha_{34}=9.8 \times 10^{6}\right.$ with $\left.\lambda=0.14\right)$ and yeasts $\left(\alpha_{34}=-5.2 \times 10^{5}\right.$ with $\left.\lambda=-0.05\right)$. The interaction between milk type and coagulant arises probably from the fact that (i) milks from different sources are contaminated differently, (ii) the pattern of proteolysis caused by rennet depends on its nature, and (iii) growth rates of microorganisms depend on the form of available nitrogen. Such interactions were of opposite sign for enterococci and Enterobacteriaceae, and this result is in agreement with prior discussion. The non-uniformity of the rate of diffusion of

TABLE 3

Physicochemical Properties of Experimental Cheeses

\begin{tabular}{lccccccc}
\hline \multicolumn{1}{c}{ Code } & $\begin{array}{c}\text { inner } \\
p H\end{array}$ & $\begin{array}{c}\text { outer } \\
p H\end{array}$ & $\begin{array}{c}\text { moisture } \\
\text { content } \\
\text { \% }(w / w)\end{array}$ & $a_{w}$ & $\begin{array}{c}\text { NaCl } \\
\text { (\% in } \\
\text { moisture })\end{array}$ & $\begin{array}{c}\text { fat } \\
\text { (\% Total } \\
\text { Solids) }\end{array}$ & $\begin{array}{c}\text { protein } \\
\text { (\% Total } \\
\text { Solids) }\end{array}$ \\
\hline 20 An A 30d & 4.45 & 5.11 & 48.60 & 0.928 & 9.94 & 52.53 & 30.92 \\
20 An A 120d & 5.68 & 6.31 & 40.65 & 0.885 & 14.96 & 56.66 & 33.23 \\
20 An B 30d & 4.85 & 5.44 & 51.01 & 0.864 & 16.86 & 51.03 & 31.45 \\
20 An B 120d & 5.68 & 6.05 & 44.91 & 0.846 & 22.73 & 53.78 & 30.66 \\
20 P A 30d & 4.55 & 5.48 & 52.16 & 0.922 & 9.76 & 54.87 & 33.72 \\
20 P A 120d & 5.56 & 5.75 & 35.86 & 0.864 & 20.08 & 57.30 & 32.34 \\
20 P B 30d & 5.07 & 5.47 & 52.18 & 0.857 & 16.86 & 53.85 & 33.64 \\
20 P B 120d & 5.58 & 5.98 & 40.50 & 0.847 & 22.82 & 58.40 & 29.80 \\
40 An A 30d & 4.54 & 5.21 & 46.94 & 0.931 & 10.57 & 57.95 & 31.94 \\
40 An A 120d & 5.60 & 5.68 & 34.80 & 0.879 & 18.19 & 55.98 & 31.79 \\
40 An B 30d & 4.83 & 5.31 & 50.70 & 0.870 & 17.00 & 51.73 & 30.95 \\
40 An B 120d & 5.54 & 5.95 & 44.69 & 0.848 & 23.34 & 52.21 & 31.07 \\
40 P A 30d & 4.60 & 5.22 & 52.60 & 0.935 & 8.21 & 54.33 & 34.77 \\
40 P A 120d & 5.25 & 5.53 & 32.40 & 0.862 & 17.72 & 56.10 & 32.82 \\
40 P B 30d & 4.60 & 5.25 & 54.29 & 0.868 & 15.18 & 55.24 & 33.74 \\
40 P B 120d & 5.55 & 5.92 & 41.33 & 0.843 & 24.68 & 53.48 & 28.48 \\
\hline
\end{tabular}

Standard error of the mean (SEM) for inner $\mathrm{pH}$ is 0.11 ; SEM for outer $\mathrm{pH}$ is 0.19 ; SEM for moisture content is 1.27 ; $\mathrm{SEM}$ for $\mathrm{a}_{\mathrm{w}}$ is 0.008 ; $\mathrm{SEM}$ for $\mathrm{NaCl}$ content is 0.54 ; SEM for fat is 0.57 ; SEM for protein is 0.58 
salt with time (as predicted by Fick's second law of diffusion) chiefly accounts for the significant interaction of salt content/ripening time.

\section{Physicochemical characteristics}

The experimental data pertaining to $\mathrm{pH}$, moisture content, $a_{\mathrm{w}}, \mathrm{NaCl}$ content, fat content and protein content are presented in Table 3.

The $\mathrm{pH}$ increased from 30 to $120 \mathrm{~d}$ of ripening, but differences between the inner and the outer regions were apparent; the inner $\mathrm{pH}$ was also generally higher in the cheeses salted by method B. This could be explained by a slower degradation of lactose to lactic acid in these cheeses during initial stages of ripening due to a smaller number of LAB. No significant differences in $\mathrm{pH}$ were found between the inner and outer regions of Picante cheese manufactured with plant or animal rennets. The inner and the outer $\mathrm{pH}$ were statistically affected at the $5 \%$ level of significance only by ripening time $\left(\alpha_{4}=0.88\right.$ with $\lambda=-1$ for the inner $\mathrm{pH}$, and $\alpha_{4}=0.58$ for the outer $\mathrm{pH}$ ).

Although Table 3 apparently shows higher levels of moisture in the cheeses manufactured with animal rennet at $120 \mathrm{~d}$ of ripening, and although these results are in agreement with those by Nuñez et al. (1991), our detailed statistical analysis indicated that coagulant type had no statistical effect at the $5 \%$ level of significance on the moisture content. Conversely (and unexpectedely) salting made a statistically significant positive contribution to moisture content $\left(\alpha_{3}=4.45\right)$, but this effect was offset by the much larger (negative) effect of ripening time $\left(\alpha_{4}=-11.67\right)$. The coagulant/ripening time is a significant twofactor interaction in terms of moisture content $\left(a_{24}=-3.63\right)$, and analysis of the data generated relating to these factors indicates that cheeses manufactured with plant rennet lose more water throughout ripening than those manufactured with animal rennet to an extent that cannot be fully accounted for by superposition of the independent effects of coagulant and ripening time.

The statistically significant (negative) effect of the coagulant on the water activity of the cheese $\left(\alpha_{2}=-0.007\right)$ was probably related to the different proteolytic activities of the two rennets; higher contents of NPN are known to reduce the water activity in cheese (Marcos et al., 1981), as a result of larger amounts of bound water. As expected, salting and ripening time had negative contributions, that were statistically significant at the $5 \%$ level, to $a_{\mathrm{w}}\left(\alpha_{3}=-0.045\right.$ and $\alpha_{4}=-0.038$ ). The salting procedure/ripening time interaction had a statistically significant effect on water activity $\left(\alpha_{34}=-0.019\right)$, so the two factors acting together are responsible for a larger decrease in water activity than if the agents were considered independently.

The $\mathrm{NaCl}$ content of the cheeses obviously depends on the salting method used, but the difference between the cheeses associated with the two patterns of salt addition remained approximately constant at ca. $6.8 \%(\mathrm{w} / \mathrm{w}$ in moisture) throughout ripening (see Table 3), except for the 20 P 120d cheeses. Salting once or twice led to different textural characteristics of the bulk cheese and the rind, as well as to different colour levels. As expected, lower values of $a_{\mathrm{w}}$ were observed in cheeses with higher $\mathrm{NaCl}$ content; however, in these cheeses moisture losses were lower at both ripening times tested when compared to the moisture losses in cheeses salted according to method A (i.e. cheeses with lower values of $\mathrm{NaCl}$ content), which are unexpected results since higher $\mathrm{NaCl}$ levels should have a higher dessicating effect. 
The total fat content of all cheeses was within the legally accepted ranges for this type of cheese (Anon., 1988). The fat content was affected at the $5 \%$ level of significance by the type of coagulant $\left(\alpha_{2}=1.46\right)$, salting procedure $\left(\alpha_{3}=-2.00\right)$ and ripening time $\left(\alpha_{4}=1.55\right)$. The total protein content of the various cheeses was apparently different. The protein content was also affected at the $5 \%$ level of significance by the type of coagulant $\left(\alpha_{2}=0.91\right)$, salting procedure $\left(\alpha_{3}=-1.47\right)$ and ripening time $\left(\alpha_{4}=-1.37\right)$. Although caprine and ovine milks are often characterized by different contents of protein and fat, our statistical analyses did not indicate that milk type affects the protein or fat contents of cheese at the $5 \%$ level of confidence. In principle, the effect of coagulant on the total fat and total protein contents would be explained by the weaker coagulum produced by plant rennet (Nuñez et al., 1991), which in turn leads to higher losses of fat and protein during syneresis; however, the opposite was observed in this research work. This phenomenon was also observed in La Serena cheese, the curd for which contained $14.0 \%$ protein and $17.3 \%$ fat when plant rennet was used, and $13.3 \%$ and $14.2 \%$, respectively, when animal rennet was used instead (Nuñez et al., 1991). The effect of $\mathrm{NaCl}$ content may be accounted for by the fact that expression of residual whey is promoted in fresh cheeses when they are rubbed with higher amounts of $\mathrm{NaCl}$.

\section{Proteolysis-Nitrogen fractions}

The results of the studies on proteolysis, i.e. changes in the different soluble nitrogen fractions, are presented in Table 4; inspection of this table indicates that there were significant differences between the values obtained for each soluble nitrogen fraction from the various experimental cheeses.

The WSN was statistically affected at the $5 \%$ level of significance by all manipulated variables $\left(\alpha_{1}=-1.31, \alpha_{2}=3.93, \alpha_{3}=-11.92\right.$ and $\left.\alpha_{4}=5.73\right)$. The WSN values for cheeses coagulated with animal rennet were lower than those for cheeses coagulated with plant rennet, irrespective of $\mathrm{NaCl}$ content, except for 20 An B 120d and 40 An A 120d cheeses. These results are in agreement with Nuñez et al. (1991), who reported that levels of $\mathrm{pH} 4.6$-soluble $\mathrm{N}$ were considerably higher throughout ripening in cheeses manufactured with plant rennet than in those manufactured with animal rennet; however, WSN values in Picante cheese manufactured with plant rennet were in general lower than those in La Serena cheese. The results for WSN indicate that gradual proteolysis occurred throughout ripening in cheeses manufactured with animal rennet, whereas for cheeses manufacturcd with plant rennet no significant differences were found between 30 and $120 \mathrm{~d}$ of ripening; however, higher proteolytic activity was exhibited by plant rennet in all cheeses (especially those ripened for $30 \mathrm{~d}$ ) than by animal rennet. Our observations are in agreement with the faster breakdown of $\alpha_{\mathrm{s} 1^{-}}$and $\beta$-caseins (with concomitant generation of higher values for $\mathrm{pH}$ 4.6-soluble $\mathrm{N}$ ) effected by plant rennet than by animal rennet reported by Nuñez et al. (1991). The fact that differences in proteolysis between cheeses ripened for 30 and $120 \mathrm{~d}$ were not significant could be due to the dominating effect of $\mathrm{NaCl}$, which is strong even in the A cheeses.

As mentioned above, two methods were used to determine NPN. The NPN values obtained by either method and depicted in Table 4 suggest continuous protein degradation in both types of cheese. The differences between the NPN levels in the cheeses manufactured by either type of rennet were not very large, 
TABLE 4

Changes in Nitrogenous Fractions During Ripening

\begin{tabular}{|c|c|c|c|c|c|}
\hline Code & $\begin{array}{c}\text { WSN } \\
\text { (\% Total } \\
\text { Nitrogen) }\end{array}$ & $\begin{array}{c}\text { NPN } \\
\text { (\% Total } \\
\text { Nitrogen) }\end{array}$ & $\begin{array}{c}T C A-N \\
\left(\mathrm{mmol}_{\text {eq.Gly }}\right. \\
\mathrm{g}^{-1} \text { cheese }\end{array}$ & $\begin{array}{c}P T A-N \\
\left(\text { mmol }_{\text {eq.Gly }}\right. \\
\left.g^{-1} \text { cheese }\right)\end{array}$ & $\begin{array}{c}\mathrm{NH}_{2}-\mathrm{N} \\
\left(\mathrm{mmol}_{\text {eq.Ler }}\right. \\
\left.\mathrm{g}^{-1} \text { cheese }\right)\end{array}$ \\
\hline 20 An A 30d & 23.47 & 12.22 & 71.26 & 32.52 & 19.83 \\
\hline 20 An A 120d & 29.87 & 21.44 & 102.63 & 92.06 & 101.83 \\
\hline 20 An B 30d & 13.37 & 6.10 & 11.90 & 2.80 & 6.67 \\
\hline 20 An B 120d & 21.56 & 12.20 & 31.39 & 26.33 & 36.97 \\
\hline 20 P A 30d & 33.85 & 16.03 & 126.50 & 40.93 & 34.24 \\
\hline $20 P A 120 d$ & 35.08 & 26.30 & 191.88 & 100.96 & 97.05 \\
\hline 20 P B 30d & 18.70 & 6.75 & 33.03 & 6.89 & 7.74 \\
\hline 20 P B 120d & 20.42 & 12.66 & 131.72 & 74.20 & 51.30 \\
\hline 40 An A 30d & 25.64 & 9.50 & 63.96 & 28.50 & 20.74 \\
\hline 40 An A 120d & 37.53 & 25.88 & 203.39 & 103.52 & 107.66 \\
\hline 40 An B 30d & 11.45 & 6.20 & 13.99 & 10.00 & 8.72 \\
\hline 40 An B 120d & 22.96 & 16.47 & 70.90 & 41.31 & 36.36 \\
\hline 40 P A 30d & 29.79 & 13.47 & 89.20 & 34.14 & 21.64 \\
\hline 40 P A 120d & 34.00 & 22.25 & 151.30 & 89.18 & 81.37 \\
\hline 40 P B 30d & 22.39 & 8.51 & 33.44 & 6.55 & 8.09 \\
\hline 40 P B 120d & 23.06 & 10.07 & 98.18 & 49.33 & 33.42 \\
\hline
\end{tabular}

WSN: Water soluble nitrogen; NPN: Non-protein nitrogen (nitrogen fraction soluble in $12 \%$ TCA) obtained by the Kjeldahl method; TCA-N: Non-protein nitrogen obtained by the spectrophotometric method; PTA-N: Nitrogen fraction soluble in $5 \%$ of PTA; $\mathrm{NH}_{2}-\mathrm{N}$ : Amino acid nitrogen; Standard error of the mean (SEM) for WSN is 0.46 ; SEM for NPN is 0.81 ; SEM for TCA-N is 1.74; SEM for PTA-N is 2.30; SEM for $\mathrm{NH}_{2}-\mathrm{N}$ is 1.68

e.g., after $120 \mathrm{~d}$ of ripening, the NPN was slightly higher in cheeses manufactured with plant rennet (with the exception of $40 \mathrm{P}$ A and $40 \mathrm{P}$ B cheeses). Only slight differences in TCA-soluble $\mathbf{N}$ could also be detected between La Serena cheeses manufactured with both types of coagulants (Nuñez et al., 1991). All manipulated variables were statistically significant at the $5 \%$ level in terms of TCA-N $\left(\alpha_{1}=-4.79, \alpha_{2}=38.23, \alpha_{3}=-69.93\right.$ and $\alpha_{4}=61.43$, with $\left.\lambda=0.22\right)$, whereas only the latter three were statistically significant in terms of NPN $\left(\alpha_{2}=0.95\right.$, ${ }_{3}=-7.93$ and $\alpha_{4}=7.99$, with $\lambda=0.18$ ). Although caprine and ovine milks have different protein (qualitative and quantitative) composition, such differences do not appear to play a role in the experimental range selected for the NPN measured by the Kjehldal method; however, this fact was not confirmed by the NPN analysed by the spectrophotometric method (i.e. TCA-N).

All factors were statistically significant at the $5 \%$ level in terms of small peptides (PTA-N) $\left(\alpha_{1}=2.69, \alpha_{2}=9.70, \alpha_{3}=-39.60\right.$ and $\left.\alpha_{4}=53.37\right)$ and amino acid nitrogen $\left(\mathrm{NH}_{2}-\mathrm{N}\right)\left(\alpha_{1}=2.15, \alpha_{2}=2.23, \alpha_{3}=-29.27\right.$ and $\left.\alpha_{4}=43.77\right)$. The observed statistically significant differences in PTA-N contrast with results by Nuñez et al. (1991). According to Heimgartner et al. (1990), plant rennet proteinases cleave casein into high molecular mass peptides, but little peptidase activity is ever observed.

In general, lower values for all soluble nitrogen fractions were found in the 
samples with a high content of $\mathrm{NaCl}$. These observations are consistent with the statistically estimated negative effect of this factor on WSN $\left(\alpha_{3}=-11.92\right)$, NPN $\left(\alpha_{3}=-7.93\right.$, with $\left.\lambda=0.18\right)$, TCA-N $\left(\alpha_{3}=-69.93\right.$ with $\left.\lambda=0.22\right)$, PTA-N $\left(\alpha_{3}=-39.60\right)$, and $\mathrm{NH}_{2}-\mathrm{N}\left(\alpha_{3}=-29.27\right)$. The aforementioned lower values are expected because, according to Guinee \& Fox (1993), the main effect of $\mathrm{NaCl}$ on cheese ripening is via its action upon water activity which in turn controls the activity of the various enzymes in cheese, although the rate of proteolysis is also known to be influenced by the ratio of casein to moisture (Lawrence et al., 1984). The relatively high levels of soluble nitrogen in cheeses with low $\mathrm{NaCl}$ contents can be attributed to a considerable activity of the microflora under those favourable environmental conditions (Schroeder et al., 1988).

\section{Proteolysis-Casein degradation}

Electrophoresis results are shown in Fig. 1. Higher levels of degradation of both $\alpha_{s^{-}}$and $\beta$-caseins were observed in cheeses salted once, i.e. those cheeses with a lower content in $\mathrm{NaCl}$. In cheeses coagulated by either animal or plant rennet and salted once, the $\alpha_{\mathrm{s}}$-caseins were readily and extensively broken down; according to Mora \& Marcos (1981), the products of the first degradation of $\alpha_{\mathrm{s}}$-caseins catalyzed by animal rennet in Manchego cheese are high molecular weight polypeptides from the acidic-C terminus with high electrophoretic mobility and soluble polypeptides from the basic- $\mathbf{N}$ terminus. Higher resistance of $\beta$-casein to enzymatic hydrolysis was observed in all experimental cheeses, which is in agreement with Marcos et al. (1976) who reported little degradation of $\beta$-casein in several cheeses manufactured from three types of milk (caprine, ovine and bovine) and coagulated with the two types of rennet used in this work.

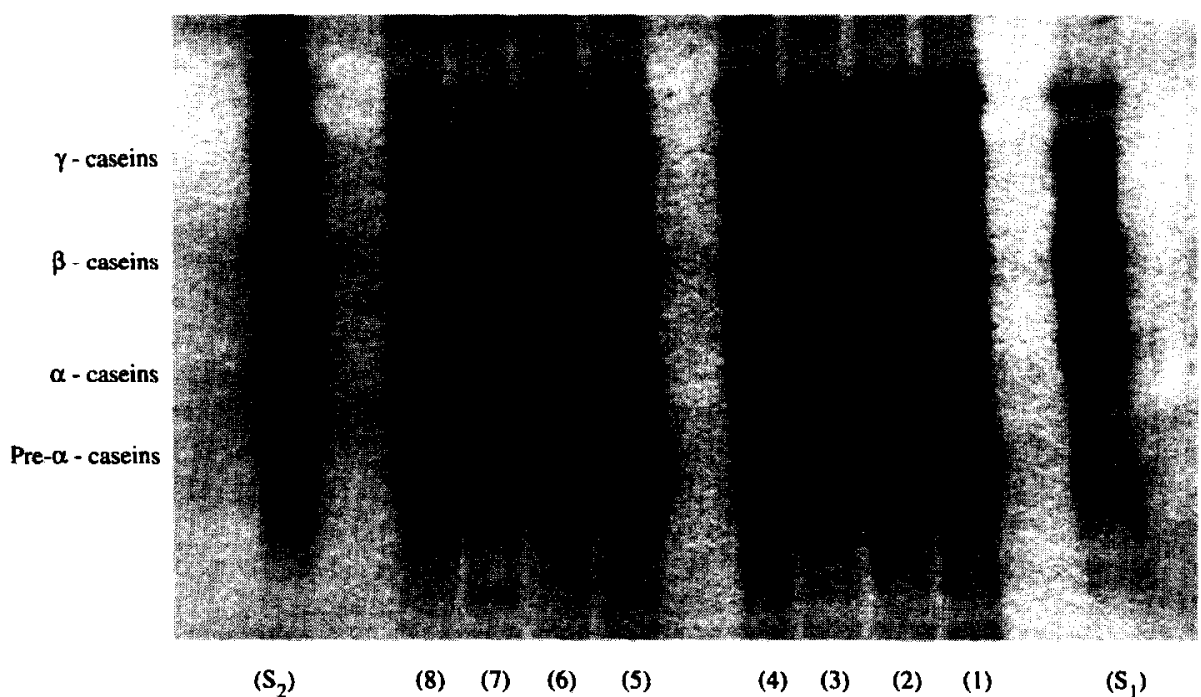

Fig. 1. Electrophoretogram of samples from cheeses manufactured from $20 \%$ caprine milk and 80\% ovine milk; ( $\left.S_{1}\right)$ Caprine casein standard; (1) 20 An A 30d; (2) 20 An A 120d; (3) 20 An B 30d; (4) 20 An B 120d; (5) 20 P A 30d; (6) 20 P A 120d; (7) 20 P B 30d; (8) 20 P B 120d; $\left(\mathbf{S}_{2}\right)$ Ovine casein standard. 
Breakdown of $\alpha_{\mathrm{s}}$ - and $\beta$-caseins was more extensive in Picante cheeses manufactured with plant rennet than in cheeses manufactured with animal rennet, especially after $120 \mathrm{~d}$ of ripening. These results agree with those reported by Nuñez et al. (1991) and Sá \& Barbosa (1972), who observed higher and more rapid degradation of $\alpha_{\mathrm{s}}$ - and $\beta$-caseins in cheese manufactured with plant rennet. The actual mechanism of the proteolytic action of plant rennet has not yet been completely established; however, Cordeiro et al. (1992) concluded that Cynara cardunculus enzymes (i.e. cardosins) exhibit unspecific hydrolytic activity on bovine milk proteins but a more specific action on ovine milk proteins. Pires et al. (1994), who studied the action of cardosins on aqueous solutions of purified bovine caseins, concluded that these enzymes are capable of hydrolysing more bonds in $\alpha_{s 1^{-}}, \alpha_{s 2^{-}}$and $\beta$-caseins than any other commercial rennet.

In cheeses salted twice, the degradation of the major caseins was more gradual than in cheeses salted only once, and such proteins were still present in cheeses ripened for $120 \mathrm{~d}$. According to Guinee \& Fox (1993), the proteolytic activity of chymosin is stimulated by increasing $\mathrm{NaCl}$ concentrations up to an optimum of ca. $6 \%(\mathrm{w} / \mathrm{w})$; while activity is inhibited at somewhat higher $\mathrm{NaCl}$ levels, proteolysis of $\alpha_{\mathrm{s} 1}$-casein occurs at up to $20 \%(\mathrm{w} / \mathrm{w}) \mathrm{NaCl}$. In contrast, degradation of $\beta$ casein by chymosin is inhibited strongly by $5 \%(\mathrm{w} / \mathrm{w})$ and completely by $10 \%(\mathrm{w} /$ w) $\mathrm{NaCl}$. Besides the intrinsically higher resistance of $\beta$-casein to hydrolysis, the relatively high $\mathrm{NaCl}$ concentration in all experimental cheeses may also have contributed to lower the rate of degradation of $\beta$-casein because, as emphasized by Guinee $\&$ Fox (1993), $\mathrm{NaCl}$ and similar solutes cause conformational changes in $\beta$-casein that render its chymosin- or pepsin-susceptible bonds less accessible to the enzyme.

Electrophoretograms of the $\mathbf{2 0}$ cheeses (Fig. 1) and the $\mathbf{4 0}$ cheeses (not shown) indicated that the molecular weight distribution of peptides produced by the two coagulants differed in that some of the pre- $\alpha_{\mathrm{s}}$-casein bands (bands with higher electrophoretic mobility than $\alpha_{\mathrm{s}}$-caseins, probably products of $\alpha_{\mathrm{s}}$-casein degradation) produced by plant rennet exhibited lower electrophoretic mobilities than those produced by animal rennet. The presence of these insoluble polypeptides decreased from 30 to $120 \mathrm{~d}$ of ripening, but such continuing proteolysis may also be effected by other agents such as proteolytic enzymes of LAB (O'Keeffe $e t$ al., 1975; Desmazeaud et al., 1976). In the cheeses manufactured with animal rennet, more extensive formation of $\gamma$-caseins was observed. $\gamma$-Caseins are formed from $\beta$-caseins by indigenous milk proteinase, plasmin (Creamer, 1975; Visser, 1977; Noomen, 1978; Richardson \& Pearce, 1981; Grufferty \& Fox, 1988a,b), and therefore their presence in cheese would be expected regardless of rennet type. However, the work of Cordeiro et al. (1992) on bovine milk proteins indicated that one of the $\gamma$-caseins is further cleaved by cardosins but not by chymosin; this would explain our observations if a similar behaviour occurred in ovine and caprine milks, although Cordeiro et al. (1992) did not obtain similar results with ovine caseins.

\section{Lipolysis}

The results for FFA index, total free fatty acids (FFA) and individual free fatty acids are tabulated in Table 5.

The FFA index was statistically affected at the $5 \%$ level of significance by the salting procedure and the ripening time $\left(\alpha_{3}=-0.923\right.$ and $\left.\alpha_{4}=1.894\right)$. The FFA 


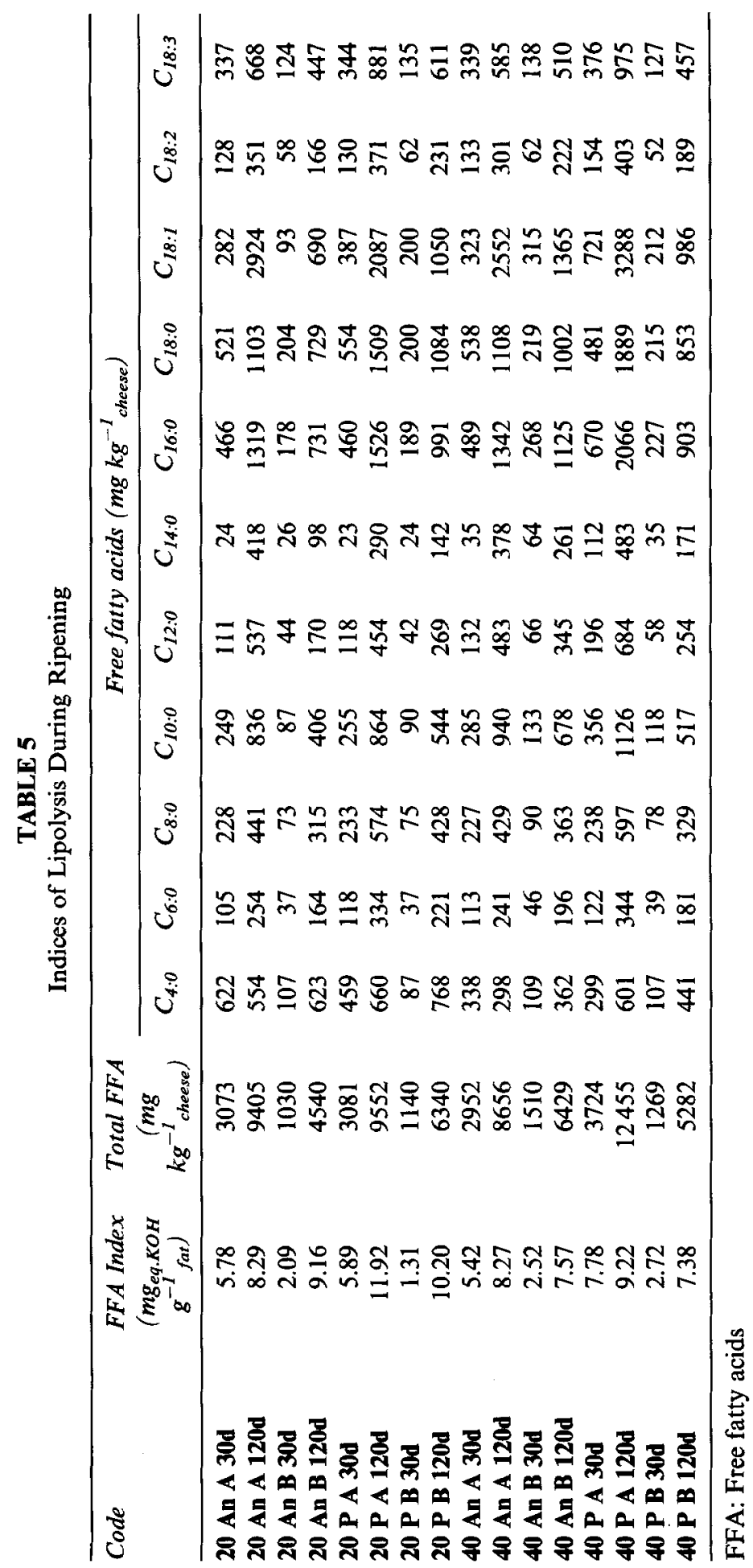


index was, in general, higher in cheeses with a lower $\mathrm{NaCl}$ content, i.e. lipolysis followed the same trend as proteolysis with respect to salt. Although inspection of Table 5 suggests that lipolytic activity was higher in cheeses prepared with plant rennet than in those prepared with animal rennet, the effect of the coagulant was not found to be statistically significant at the $5 \%$ level.

The ripening time and the salting procedure were also the statistically significant factors affecting the overall release of free fatty acids $\left(\alpha_{3}=-3170\right.$ and $\left.\alpha_{4}=5610\right)$ as well as the release of all individual free fatty acids $\left(\alpha_{3}=-153.1\right.$ and $\alpha_{4}=272.5$ for $\mathrm{C}_{4: 0} ; \alpha_{3}=-88.6$ and $\alpha_{4}=164.7$ for $\mathrm{C}_{6: 0} ; \alpha_{3}=-152.0$ and $\alpha_{4}=279.4$ for $\mathrm{C}_{8: 0} ; \alpha_{3}=-291.8$ and $\alpha_{4}=542.1$ for $\mathrm{C}_{10: 0} ; \alpha_{3}=-183.3$ and $\alpha_{4}=303.9$ for $\mathrm{C}_{12: 0}$; ${ }_{3}=-117.8$ and $\alpha_{4}=237.3$ for $C_{14: 0} ; \alpha_{3}=-465.9$ and $\alpha_{4}=881.9$ for $C_{16: 0}$; ${ }_{3}=-399.7$ and $\alpha_{4}=793.2$ for $C_{18: 0} ; \alpha_{3}=-956.8$ and $\alpha_{4}=1551.1$ for $C_{18: 1}$; ${ }_{3}=-116.0$ and $\alpha_{4}=182.1$ for $C_{18: 2} ;$ and $\alpha_{3}=-244.8$ and $\alpha_{4}=401.8$ for $C_{18: 3}$ ). In all cases the $\mathrm{NaCl}$ content contributed negatively to lipolysis whereas the ripening time contributed positively. Differences in the concentration of the various free fatty acids increased substantially during ripening. For most individual free fatty acids analysed, the highest concentrations were found in $40 \mathrm{P}$ A $120 \mathrm{~d}$ cheeses; an exception was butyric acid for which the highest content was found in the 20 P B 120d cheeses.

In the case of butyric and capric acids, the effect of milk was also significant $\left(\alpha_{1}=165.6\right.$ and $\alpha_{1}=-102.7$, respectively). Ovine and caprine milk fats contain considerably higher proportions of butyric, caproic, caprylic, capric and lauric acids and considerably lower proportions of unsaturated fatty acids than bovine fat (Lowenstein et al., 1980; Anifantakis, 1986; González-Llano \& Ramos, 1989). Data reported by Nájera et al. (1993) indicate that capric and, to a lesser extent, butyric acids are present at higher percentages in caprine milk cheeses than in ovine milk cheeses; those results agree only partially with our results, viz. higher levels of butyric acid were found in cheeses manufactured from the milk blend containing the higher level of ovine milk ( 20 cheeses) whereas higher levels of capric acid were found in cheeses manufactured from the milk blend containing the higher level of caprine milk ( $\mathbf{4 0}$ cheeses).

Which significant two-factor interactions exist with regard to lipolysis depends on the free fatty acid in question, although the most commonly encountered was clearly salting procedure/ripening time.

\section{Organoleptic considerations}

According to Barbosa et al. (1981), plant rennets are not suitable for the manufacture of cheeses with a medium to long ripening period. The flavour of 'longhold' cheeses is generally better and stronger when calf rennet is used at levels low enough to avoid bitterness (Lawrence \& Gilles, 1971; Birkkjaer \& Johnk, 1985). The texture of Picante cheeses manufactured with plant rennet, especially those with a lower $\mathrm{NaCl}$ content, by $30 \mathrm{~d}$ of ripening was softer than of those manufactured with animal rennet with a higher content of $\mathrm{NaCl}$. Not withstanding the fact that the high content of $\mathrm{NaCl}$ in Picante cheese may pose health problems to some consumer groups, the influence of $\mathrm{NaCl}$ on cheese characteristics is very important; e.g. cheeses salted once (A cheeses) become very dry after $120 \mathrm{~d}$ of ripening and exhibited unpleasant and poor visual appearance. The proportion of caprine and ovine milks was apparently not important for the final characteristics of the cheese. 


\section{ACKNOWLEDGEMENTS}

The authors are grateful to the members of the technical board of the Governmental Directorate of Agriculture of the Region of Beira Interior (DRABI, Portugal) for their cooperation in supervising the local manufacture of cheeses according to the design presented and in transporting such cheeses to the ESB premises. Financial support for author A. C. F. was provided by a Ph.D. fellowship within the Programme for the Creation of National Infrastructures in Applied Science and Investigation (CIENCIA) administered by the National Board for Scientific and Technological Investigation (JNICT, Portugal). Partial financial support for the research expenses was provided by project MAQUETTE: Improvement of traditional cheeses and their technology, administered by the Innovation Agency (AI, Portugal). The cooperation of Dr. Javier Carballo (University of Vigo, Galicia), Bernardo Prieto and Dr. Jose Maria Fresno Baro (University of Léon, Castilla y Léon) in the performance of some detailed experimental analyses is gratefully acknowledged. The careful reading of the manuscript and the critical suggestions by Prof. Patrick Fox (University College Cork, Ireland) are also gratefully acknowledged.

\section{REFERENCES}

Adler-Nissen, J. (1979). Determination of the degree of hydrolysis of food protein hydrolysates by trinitrobenzenesulfonic acid. J. Agric. Food Chem., 6, 1256-1262.

Andrews, A.T. (1983). Proteinases in normal bovine milk and their action on caseins. $J$. Dairy Res., 50, 45-55.

Anifantakis, E.M. (1986). Comparisons of the physico-chemical properties of ewe's and cow's milk. Bulletin 202, International Dairy Federation, Brussels, pp. 42-53.

Anon. (1975). ISO 3433 - Fromages. Determination de la teneur en matière grasse. Methode Van Gulik.

Anon. (1988). Decreto Lei n 22/88 de 28 de Maio. Diário da República, Imprensa Nacional Casa da Moeda.

Barbosa, M., Corradini, C. \& Battistotti, B. (1981). Cheesemaking experiments carried out on some Italian cheese with vegetable rennet from cardo (Cynara cardunculus L.). Sci. Tecn. Latt.-Casearia, 32, 203-221.

Biss, K. (1991). Sheep and goat cheese. J. Soc. Dairy Technol., 44, 104-106.

Birkkjaer, H. \& Johnk, P. (1985). Technological suitability of calf rennet substitutes. Bulletin 194, International Dairy Federation, Brussels, pp. 8-13.

Blakesley, R.W. \& Boezi, J.A. (1977). A new staining technique for proteolysis in polyacrylamide gels using Coomassie Brilliant Blue G-250. Anal. Biochem., 82, 580581.

Box, G.E.P., Hunter, W.G. \& Hunter, J.S. (1978). In Statistics for Experimenters - An Introduction to Design, Data Analysis, and Model Building. Wiley, New York, pp. 239240 and 306-351.

Busta, F.F., Peterson, E.H., Adams, D.M. \& Johnson, M.G. (1984). Colony count methods. In Compendium of Methods for the Microbiological Examination of Foods, ed. M.L. Speck. American Public Health Association, Washington DC, pp. 62-82.

Cordeiro, M., Jakob, E., Puhan, Z., Pais, M.S. \& Brodelius, P.E. (1992). Milk clotting and proteolytic activities of purified cynarases from Cynara cardunculus - a comparison to chymosin. Milchwissenschaft, 47, 683-687.

Creamer, L.K. (1975). $\beta$-Casein degradation in Gouda and Cheddar cheese. J. Dairy Sci., 58, 287-292. 
Cruz, A.A. (1945). Lacticınios da Beira Baixa: Queijo à ovelheira e queijo à cabreira. Boletim Pecuário (Lisboa), 12, 55-100.

Desmazeaud, M.J., Gripon, J.C., Le Bars, D. \& Berger, J.L. (1976). Étude du rôle des microorganisms et des enzymes au cours de la maturation des fromages. III. Influence des microorganisms. Lait, 56, 379-396.

Farkye, N.Y., Kiely, L.Y., Allshouse, R.D. \& Kindstedt, P.S. (1991). Proteolysis in Mozarella cheese during refrigerated storage. J. Dairy Sci., 74, 1433-1438.

Folkertsma, B. \& Fox, P.F. (1992). Use of Cd-ninhydrin reagent to assess proteolysis in cheese during ripening. J. Dairy Res., 59, 217-224.

Freitas, A.C., Sousa, M. \& Malcata, F.X. (1995s). Effect of ripening time and the combination of ewe and goat milk on the microflora of Picante cheese. Ital. J. Food Sci., 7, 361-377.

Freitas, A.C., Pais, C., Malcata, F.X. \& Hogg, T.A. (1996). Microbiological characterization of Picante da Beira Baixa cheese. J. Food Protect., 59, 155-160.

Garcia, H.S., Reyes, H.R., Malcata, F.X., Hill, C.G. \& Amundson, C.H. (1990). Determination of the major free fatty acids in milkfat using a three-component mobile phase for HPLC analysis. Milchwissenschaft, 45, 757-759.

Gaya, P., Medina, M. \& Nuñez, M. (1983). Accelerated decrease of Enterobacteriaceae counts during ripening of raw milk Manchego cheese by lactic culture inoculation. $J$. Food Prot., 46, 305-308.

González-Llano, D. \& Ramos, M. (1989). Composición química de la leche de oveja. Ovis, 2, 9-10.

Grufferty, M.B. \& Fox, P.F. (1988a). Milk alkaline proteinase. J. Dairy Res., 55, 609 630.

Grufferty, M.B. \& Fox, P.F. (1988b). Factors affecting the release of plasmin activity from casein micelles. N.Z. J. Dairy Sci. Technol., 23, 153-163.

Guinee T.P. \& Fox, P.F. (1993). Salt in cheese: physical, chemical and biological aspects. In Cheese: Chemistry, Physics and Microbiology, ed. P.F. Fox, Chapman \& Hall, London, pp. 257-302.

Heimgartner, U., Pietrzak, M., Geertsen, R., Brodelius, P., Da Silva Figueiredo, A.C. \& Pais, M.S.S. (1990). Purification and partial characterization of milk clotting proteases from flowers of Cynara cardunculus. Phytochemistry, 29, 1405-1410.

Kosikowski, F.V. 1982. Cheese and Fermented Milk Foods. Edwards Brothers, New York, pp. $560-597$.

Kuchiov, C.N. \& Fox, P.F. (1982). Soluble nitrogen in Cheddar cheese, comparison of extract procedures. Milchwissenschaft, 37, 331-335.

Lawrence, R.C. \& Gilles, J. (1971). The use of rennet in cheesemaking. N.Z. J. Dairy Sci. Technol., 6, 30.

Lawrence, R.C., Heap, H.A. \& Gilles, J. (1984). A controlled aproach to cheese technology. J. Dairy Sci., 67, 1632-1645.

Lowenstein, M., Stephen, J.S., Harold, M.B. \& Frank, J.F. (1980). Research on goat milk: a review. J. Dairy Sci., 63, 1631-1636.

Marcos, A., Alcalá, M., Fernandez-Salguero, J. \& Esteban, M.A. (1981). Water activity and chemical composition of cheese. J. Dairy Sci., 64, 622-626.

Marcos, A., Esteban, M.A. \& Fernandez-Salguero, J. (1976). Influence of some chemical and physical factors on the proteolysis of cheese caseins. Arch. Zoot., 25, 73-86.

Marshall, B.Y., Ohye, D.B. \& Christian, J.H.B. (1971). Tolerance of bacteria to high concentration of $\mathrm{NaCl}$ and glycerol on the growth medium. J. Appl. Microbiol., 21, 363 364.

Measures, J.C. (1975). Role of amino acids in osmoregulation of nonhalophilic bacteria. Nature, 257, 398-400.

Miles, A.A. \& Misra, S.S. (1938). The estimation of the bactericidal power of the blood. $J$. Hyg., 38, 732-749.

Mora, T. \& Marcos, A. (1981). Proteolysis in Manchego cheese: casein breakdown and their insoluble degradation products. Arch. Zoot., 30, 139-155. 
Nájera, A.I., Barrón, L.J.R. \& Barcina, Y. (1993). Lipid fraction composition of cow's, sheep's, and goat's cheese, and the influence on its quality. Rev. Esp. Cienc. Tecnol. Aliment., 33, 345-363.

Noomen, A. (1978). Activity of proteolytic enzymes in simulated soft cheeses (Meschanger type) 1 . Activity of milk protease. Neth. Milk Dairy J., 32, 26-49.

Nuñez, M., Fernandez del Pozo, B., Rodríguez-Marín, M.A., Gaya, P. \& Medina, M. (1991). Effect of vegetable and animal rennet on chemical, microbiological, rheological and sensory characterization of La Serena cheese. J. Dairy Res., 58, 511-519.

Nuñez, M., Garcia-Aser, C., Rodríguez-Martín, A., Medina, M. \& Gaya, P. (1986). The effect of ripening and cooking temperatures on proteolysis and lipolysis in Manchego cheese. Food Chem., 21, 115-123.

Nuñez, M., Gaya, P. \& Medina, M. (1985). Influence of manufacturing and ripening conditions on the survival of Enterobacteriaceae in Manchego cheese. J. Dairy Sci., 68, $794-800$.

O'Keeffe, R.B., Fox, P.F. \& Daly, C. (1975). Proteolysis in Cheddar cheese; influence of the rate of acid product during manufacture. J. Dairy Res., 42, 111-122.

Pires, E., Faro, C., Macedo, I., Esteves, C., Morgado, J., Veríssimo, P., Pereira, D. \& Gomcs, D. (1994). Flor do cardo versus quimosina no fabrico de queijos artesanais. Química, 54, 66-68.

Richardson, G.H. (ed.) (1985). Standard Methods for the Examination of Dairy Products, American Public Health Association, Washington DC.

Richardson, B.C. \& Pearce, K.N. (1981). The determination of plasmin in dairy products. N.Z. J. Dairy Sci. Technol., 16, 209-220.

Sá, V. \& Barbosa, M. (1972). Cheese-making with a vegetable rennet from cardo (Cynara cardunculus). J. Dairy Res., 39, 335-343.

Schroeder, C.L., Bodyfelt, F.W., Wyatt, C.J. \& McDaniel, M.R. (1988). Reduction of sodium chloride in Cheddar cheese: effect on sensory, microbiological, and chemical properties. J. Dairy Sci., 71, 2010-2020.

Visser, F.M.W. (1977). Contribution of enzymes from rennet, starter bacteria and milk to proteolysis and flavour development in Gouda cheese. Neth. Milk Dairy J., 31, 120-133. 